\title{
Risk Management of the Project and the Use of Software in SME
}

\author{
K. VICHOVA ${ }^{1 *}$, P. TARABA ${ }^{1}$, T. BELANTOVA ${ }^{2}$ \\ ${ }^{1}$ Faculty of Logistics and Crisis Management, \\ Tomas Bata University in Zlín \\ Studentské náměstí 1532, 68601 Uherské Hradiště \\ ${ }^{2}$ Faculty of Management and Economics, \\ Tomas Bata University in Zlín, \\ Mostní 5139, 76001 Zlín \\ CZECH REPUBLIC
}

\begin{abstract}
Today we live in a time when it is necessary to try to minimize risks to the lowest possible level of risk. There are several risks in the SMEs as the environmental, economic and others. We do not constantly manage to eliminate the risks. For risk management purposes, the use of project risk management using software is appropriate. Today, it offers a plethora of software that allows them to be used. Thanks to this software, work is simplified, and there is no human error. The aim of this article would be to analyze the risks in small and medium enterprises. For this purpose, Pareto analysis, Chi-squared test were used, and the most significant risks were evaluated. Furthermore, the methods used in risk management were assessed. In the conclusion of the paper, the results of the work were summarized, and recommendations for small and mediumsized enterprises in the field of project risk management were proposed.
\end{abstract}

Key-Words: - Risk management, Project management, Software tool, SME, Business and Economics.

Received: September 19, 2019. Revised: May 14, 2020. Re-revised: May 27, 2020. Accepted: June 1,

2020. Published: June 4, 2020.

\section{Introduction}

There is an increasing number of enterprises in the Czech Republic and in the world. In total, 99 percent of the enterprises in most developer countries are SMEs [1]. SMEs are one of the essential parts of the knowledge economy. Golej [2] often characterized SME in Germany by a strong product orientation, technical expertise, and underexposure of process orientation and project management capabilities. Lückmann [3] OECD remark, that SMEs are a dominant force in economies worldwide, forming the backbone of wealth-generating activities in most industrialized nations [4].

Given the importance of today's economies and the fact that entrepreneurial SMEs are purported to by catalysts of the future global economy [5] there is a need to gain insight into the development of key entrepreneurial capabilities to increase SME survival and growth. Renton [6] in the enterprises are several managers, which must manage the proper operation of the company. However, based on these situations there may be a situation of crisis.
In these situations it is necessary to have the employee which will solve the project risk management. Risk can be seen as the possibility of economic or financial losses or gains, as a consequence of the uncertainty associated with pursuing a course of action [7]. Risk management is regarded as one of the main factors in the designing and management of the venture [8]. Urciuoli [9] defines risk management as the process to safeguard the assets of the company against losses that may hit it in the exercise of its activities, through the use of instruments of various kinds and the best cost conditions. The research project has expanded during the last decades [10]. In this part, it is necessary to remark, that the identity and assessment of the risk is the main step in project risk management [11]. All enterprises need to adopt a risk management strategy and methodology to identify, assess and treat risk [12]. On the other hand, the implementation of risk management can be a complicated one that requires a wide range of knowledge, skills and resources [1]. 
At the national level, the issue of small and medium-sized companies is addressed by authors from various perspectives, but there is no comprehensive approach to project risk management [13]. For instance, in the Czech Republic, Virglerová et al. [14] deal with the issue of risk management in SMEs, which focuses mainly on financial risk management in relation to the education of the SME owners. It was found that SME owners with lower education had higher satisfaction with the role of the state in the business environment of the Czech Republic. SME owners with higher education were more aware of risks. According to Virglerová et al. [14] the majority of SMEs were not satisfied with the financial support from the state. Belás [15] describes the business risks of SMEs in the Czech and Slovak Republic in general. In the Czech conditions dealing with risk management, Trkovský [16], Doležal et al. [17], and Taraba [18]. In foreign literature, the issue of project risk is elaborated in more detail in the monographs of Kerzner [19] Kendrick [20] or Hillson [21].

The fundamental theoretical background is complemented by publications published by international organizations covering the field of project management worldwide: Project Management Institute [22]; [23] and International Project Management Association [24]. The authors of this paper are aware of the limited possibilities of small and medium-sized companies, especially in the field of risk management of projects, which led to the submission of the research project - Project risk management in the conditions of small and medium-sized enterprises in the Czech Republic GA/16/2019 financed by Grant Agency Academia Aurea (GAAA).

The main goal of the project is to analyze the level of risk management of projects in the conditions of small and medium enterprises operating in the Czech Republic, compare the results of the survey with relevant research conducted in the Czech Republic and abroad and propose recommendations to increase the level of risk management.

Risk management is an essential part of effective project management, as all projects are exposed to risks. Part of the risk management process in small and medium-sized enterprises is the design of a set of measures to minimize risks. As part of risk prevention, preventive measures are set, such as insurance and the creation of reserves. If the risk occurs, it is mainly a reduction of the level of risk (reduction of the negative impact, reduction of the probability of its occurrence).
Through the implementation of individual stages, the secondary objectives of the project are continuously fulfilled, namely the expansion of knowledge in the field of company management among representatives of small and medium-sized enterprises in the Czech Republic. By publishing the results in journals indexed in the SCOPUS databases and in impact journals, the results are disseminated to the professional.

When solving the project, the research team under the leadership of the leading researcher cooperates with small and medium-sized enterprises that carry out their business activities in the Czech Republic and with authors who focus on the approach of risk management.

The approach to the risk management process can be divided into traditional, progressive, and strategic.

Tab. 1 Approaches of enterprise risk management [25]

\begin{tabular}{|ll|}
\hline \multicolumn{1}{|c|}{ Traditional approach } \\
\hline 1. & Risk identification, loss control and complains analysis \\
\hline 2. & $\begin{array}{l}\text { Increase ability to meet corporate objectives ensuring } \\
\text { that risks are taken into consideration in the decisions }\end{array}$ \\
\hline 3. & Improve management of the interrelated risks across the organization \\
\hline & Progressive approach (Traditional approach plus) \\
\hline 1. & Business continuity, total risk cost, education and communication \\
\hline 2. & Improve competences to identify and assess risks \\
\hline 3. & Improve management and responsibility of the business units \\
\hline 4. Internal auditing takes the risk issues for discussio \\
\hline Strategic approach (Traditional and progressive approaches plus) \\
\hline 1. ERM across the organization and use of technology \\
\hline 2. Risk issues are part of business strategic discussions \\
\hline 3. & $\begin{array}{l}\text { Risk sources are gathered across all levels of the organization and with } \\
\text { the stakeholders }\end{array}$ \\
\hline
\end{tabular}

In an attempt to converge the concepts of the above structures, the authors notice that the initial and basic stages are similar to the traditional approach. The defined and operational stages of projects are encompassed in the progressive approach and the advanced stage of projects is similar to strategic approach [25].

Rezakhani [26] notes that each engineering expertise should use specialized risk management tool as shown in table 2 for risk analysis depending on the project phase. 
Tab. 2 Key expertise for risk analysis by project phase [26]

\begin{tabular}{|c|c|c|c|c|}
\hline Discipline & $\begin{array}{c}\text { Planning/ } \\
\text { Programming }\end{array}$ & $\begin{array}{c}\text { Preliminary } \\
\text { Engineering }\end{array}$ & $\begin{array}{c}\text { Final } \\
\text { Design }\end{array}$ & Construction \\
\hline Planning & $\mathrm{x}$ & $\mathrm{x}$ & & \\
\hline Environmental & $\mathrm{x}$ & $\mathrm{x}$ & $\mathrm{x}$ & $\mathrm{x}$ \\
\hline Funding Approval & $\mathrm{x}$ & $\mathrm{x}$ & $\mathrm{x}$ \\
\hline Project Management & $\mathrm{x}$ & $\mathrm{x}$ & $\mathrm{x}$ \\
\hline Engineering & & $\mathrm{x}$ & $\mathrm{x}$ & $\mathrm{x}$ \\
\hline Civil, Structual, Systems & & $\mathrm{x}$ & $\mathrm{x}$ \\
\hline Cost Estimating & & $\mathrm{x}$ & $\mathrm{x}$ & $\mathrm{x}$ \\
\hline Scheduling & & $\mathrm{x}$ & $\mathrm{x}$ & $\mathrm{x}$ \\
\hline Budgeting Controls & & & $\mathrm{x}$ \\
\hline Real Estate/Righr of Way & & & $\mathrm{x}$ \\
\hline Construction Management/Oversight & & & $\mathrm{x}$ \\
\hline Constructability/Contractor & & & $\mathrm{x}$ \\
\hline Rther Technical (e.g. Legal, Permitting, Procurement) & & & $\mathrm{x}$ & $\mathrm{x}$ \\
\hline
\end{tabular}

At each stage of the project, different key expertise is desirable. The letter $X$ indicates which key expertise is highly desirable at a given stage of the project. If the key expertise does not have an $\mathrm{X}$, it means that the key expertise is desirable but optional given the circumstances of the project [26].

Verbeno [12] based on the study found out, that project risk management is implemented in 9 percent of the enterprises. Projects often face cost overruns during the implementation phase; hence a proactive approach is essential for monitoring project costs and detection of potential problems [27]. Project management plays a key role and hence a proper emphasis must be placed in selecting the project team that ensures proper decision making at various stages of the project life cycle, and results in timely project completion and hence project success [28]. Tuysuz [28] defines project risk management as one of the nine main knowledge areas of the project management institute's project management body of knowledge. The aim of the paper is to analyze the use of project risk management and the use of project management software in the SMEs in the Czech Republic.

\section{Software for Project Management in small and medium enterprises}

New technologies play an essential role in many areas of human activity today. Computer hardware, software, and networks, or the use of interdisciplinary and global teams, have radically changed the work environment [29]. General mathematical and statistical tools and graphical methods and techniques are used for project management [30]. According to Dvořák, Kališ and Sirůček [31] essential tools for project management support in Small and Medium Enterprises (SME) are software tools to support work in the field of project management and project portfolio management. Doležal [17] noted that such software will always be only a tool, support for the implemented system, never a miraculous solution that will eliminate all problems. According to Basl and Blažíček [32] the deployment of information systems in the form most often symbolized by applications referred to as 
Enterprises Resource Planning (ERP), not only in our country, began more than thirty years ago.

Within project management, software support is used; for example, in the time planning of a project, especially in the graphical representation of the course of activities over time. Based on the WorkBreakdown Structure (WBS), a Gantt chart or Network chart is created [33]. A Gantt chart is a standard format for graphically capturing project schedule information that lists individual project tasks. The network diagram is processed according to the Critical Path Method (CPM) or according to Program evaluation and review technique (PERT). The CPM method assumes a deterministic duration of activities. The network graph in this method depicts a sequence of activities and, among other things, depicts a critical path, the color of which is typically red. The critical path consists of critical activities. There is at least one critical path in each network graph that leads from the start node to the end node. The critical path is thus the longest path in the graph, which implies the fact that extending the duration of activities on this path leads to extending the duration of the entire project. Unlike the CPM method, the PERT assumes a stochastic duration of activities. For this method, three duration estimates are entered for each activity (estimate of optimistic duration, the estimate of most probable duration, and the estimate of pessimistic duration). In the real world, it is difficult to find examples in which the optimistic duration and the pessimistic duration of the activity are symmetrically divided. In project management, there is a much more common division, which is asymmetric. Activity durations are assumed to be random variables with a Beta distribution [34]. For both methods, it is appropriate to use software tools for project management. When managing risks, it is possible to use tools of standard office suites (e.g., MS Excel), or for quantitative methods and simulations (Monte Carlo and predictive modeling tools) it is, for example, SW Crystal Ball from Oracle.

SME has many options when choosing a suitable software tool. Software for project management can be divided according to whether it is a paid license or this SW tool is available as open-source. Typical paid SW tools used in SMEs are Microsoft's Project tools. MS Project tools cover all key areas of project management and project portfolio management, whether you look at them from the perspective of world-renowned certification authorities (eg PMI or PRINCE II), as well as from users who they come into everyday working contact with these products [31].
Other products used in Czech companies include SW Primavera from Oracle. A typical representative of open-source software for project management is Project Libre. Project Libre can be used as a replacement for Microsoft Project and other commercial applications to prepare a project schedule. Project Libre uses standard planning functionality that you are used to from other products. Other SW products that can be used mainly in SMEs include Basecamp, Gantt project, Merlin project, or Easy project. However, it is always necessary to adapt the selection of a specific SW tool to the requirements of the company, which should take into account the specifics of the company's policy and the overall approach to project solutions.

\section{Methodology}

Four methods of scientific work were used in this paper. The method of analysis is used because it uses the principles of logic to achieve the set goal and provide the framework to explore risks in the SME and the use of software for project management. The induction method was used, where this method serves to examine the fact of creating a hypothesis from the points obtained. The comparison method allows us to evaluate and analyze risks in SME. Finally, there was used for the survey. Based on this survey we take an overview of the risk to the effects of the SME. There was used the Pareto analysis for the evaluation.

Pareto's analysis is based on Pareto's rule. This principle indicates that a small group of causes or phenomena is of fundamental importance, and a large group of causes and phenomena is of negligible significance. Based on this analysis it is possible to find out which phenomena are significant for the organization and it is necessary to pay attention to them. Conversely, aspects whose impact on an organization is negligible can be determined. It will save the organization's resources.

The process of implementing the Pareto analysis involves creating a chart that appropriately captures critical and less critical phenomena and causes.

The Pareto analyses consist of the following steps:

1. Determination of the subject of analysis and list of examined categories.

2. Data Collection.

3. Arrangement and preparation of data for analysis.

4. Creating a Bar Graph.

5. Decisions on the following steps and their implementation. 
After meeting points $1-4$, a chart will be created, and a decision on the next steps could be made. The graph also includes a Lorenz curve that can help separate key and less critical phenomena [35].

The chi-square test (a chi-squared test- $\chi 2$ test) was used to verify the hypotheses statistically. For this category of significance tests, it is established whether the frequencies obtained by measuring in business practice differ from the theoretical frequencies that correspond to the given null hypothesis.

The Chi-squared statistic is the sum of the squares of the differences of the observed (real, empirically determined) and expected frequency (the frequency that corresponds to the formulated null hypothesis) divided by the expected frequency for every cell. The formula for the chi-square statistic used in the chisquare test is:

$$
\chi_{\mathrm{s}}^{2}=\sum \frac{\left(0_{\mathrm{i}}-\mathrm{E}_{\mathrm{i}}\right)^{2}}{\mathrm{E}_{\mathrm{i}}}
$$

Where:

$\chi^{2}$ is the test criterion;

"c" is the degrees of freedom;

"O" is the observed value;

"E" is the expected value.

\section{Results}

In this part of the paper, we would like to present results from the survey. The survey was sent to five hundred enterprises. These enterprises were of the three types - small, medium, and large. The purpose of this paper was to use only the results from the SME. In total, we take the feedback from 106 enterprises. The aim of this paper was to analyze risks, which must be the solution in SME. For this purpose, we used the mentioned Pareto analysis.

Tab. 3 The evaluation of the risks in SME

\begin{tabular}{|l|c|c|c|}
\hline \multicolumn{1}{|c|}{ Risks in SME } & Frequency & Relative frequency & $\begin{array}{c}\text { Commulative } \\
\text { relative frequency }\end{array}$ \\
\hline Technical-technological & 3 & 0.0125 & 0.0125 \\
\hline Political & 8 & 0.0333 & 0.0458 \\
\hline Environmental & 13 & 0.0541 & 0.0999 \\
\hline Productive & 16 & 0.0666 & 0.1665 \\
\hline Legislative & 27 & 0.1125 & 0.279 \\
\hline Financal & 31 & 0.1291 & 0.4081 \\
\hline Market & 33 & 0.1375 & 0.5456 \\
\hline Economics & 49 & 0.2041 & 0.7497 \\
\hline Human resources & 60 & 0.25 & 1 \\
\hline
\end{tabular}




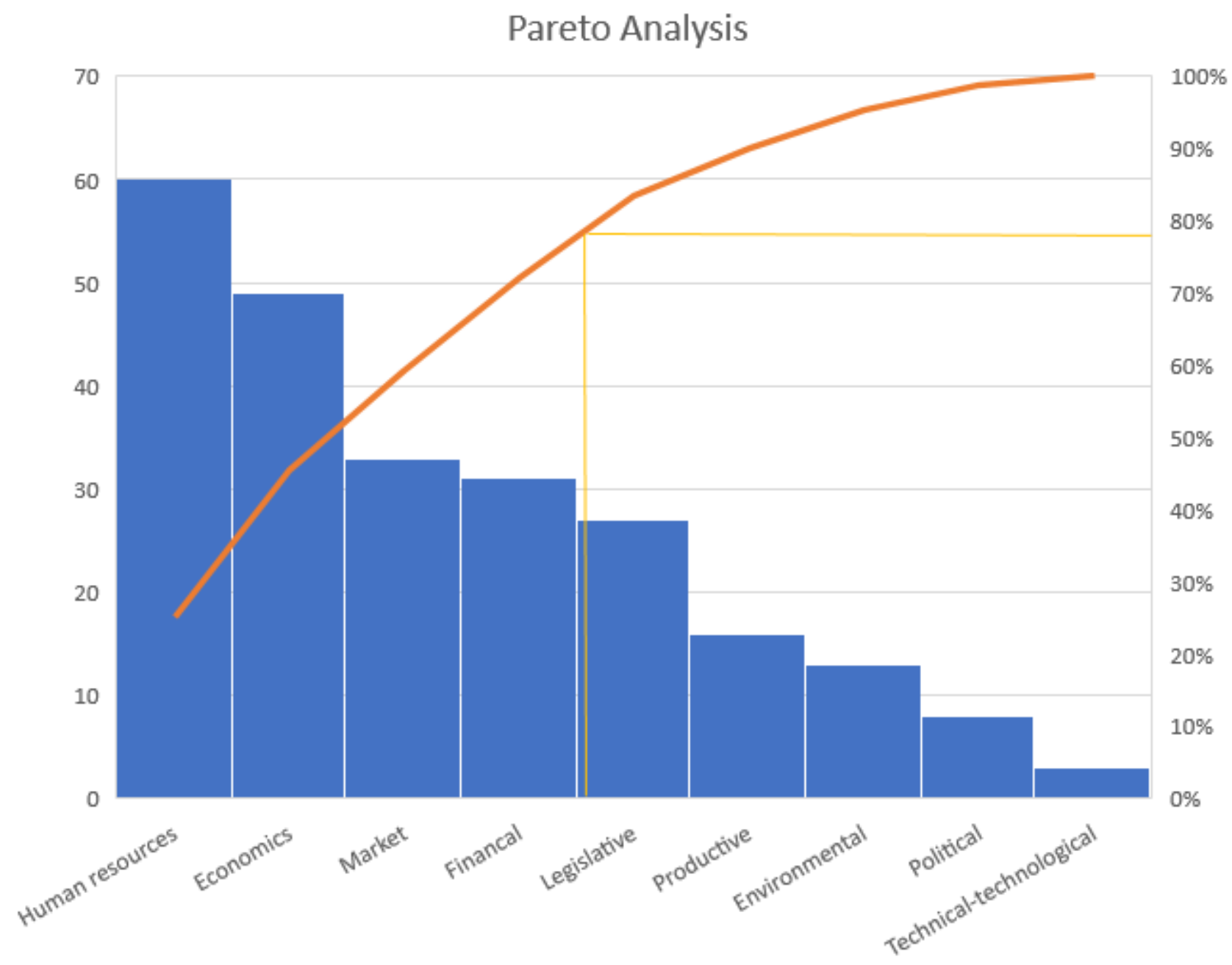

Fig. 1 Pareto analysis in SME

Fig. 1 shows the results of the Pareto analysis in SME. As can be seen, the risks, which the SME must pay attention are human resources, economics, market, and financial risks. On the other hand, the legislative, productive, environmental, political, technical-technological risks we could pay little attention to the SME.

Secondly, there was used the chi-square test. There was defined hypothesis for the determination of the result of this paper. This hypothesis was tested at the significance level of $\mathrm{p}$-value 0.05 . Alpha level is $0.05(5 \%)$.

Hypothesis H0: The observed risks in small and medium-sized enterprises are the same.

Hypothesis H1: The observed risks in small and medium-sized enterprises are different. 
Table. 4 Chi-square

\begin{tabular}{|l|c|c|c|c|c|}
\hline \multicolumn{1}{|c|}{ Risks in SME } & Frequency & $\mathrm{O}$ & $\mathrm{O}-\mathrm{P}$ & $(\mathrm{O}-\mathrm{P})^{2}$ & $\left((\mathrm{O}-\mathrm{P})^{2}\right) / \mathrm{O}$ \\
\hline Technical-technological & 3 & 26.7 & 23.7 & 561.7 & 21 \\
\hline Political & 8 & 26.7 & 18.7 & 349.7 & 13 \\
\hline Environmental & 13 & 26.7 & 13.7 & 127.7 & 7 \\
\hline Productive & 16 & 26.7 & 10.7 & 114.5 & 4.3 \\
\hline Legislative & 27 & 26.7 & 0.3 & 0.09 & 0.003 \\
\hline Financal & 31 & 26.7 & 4.3 & 18.39 & 0.69 \\
\hline Market & 33 & 26.7 & 6.3 & 39.7 & 1.5 \\
\hline Economics & 49 & 26.7 & 22.3 & 497.3 & 18.6 \\
\hline Human resources & 60 & 26.7 & 33.3 & 1108 & 41.5 \\
\hline$\sum$ & 240 & 240 & - & - & 107.6 \\
\hline
\end{tabular}

We found, that for a significance level of 0.05 and several degrees of freedom of 8 the critical value of the test criterion is:

$$
\chi^{2} 0.05(8)=15.507
$$

The calculated value of the test criterion $\chi^{2}=107.6$. It means that this value is greater than the critical value $\chi_{0.05}^{2}(8)=15.507$. Thanks to this finding, we reject the null hypothesis and accept the alternative hypothesis. Based on this test we take the information, that the risks in small and medium-sized enterprises are different.

The third part of the results was to analyzed the use of methods for the risk management in SME.

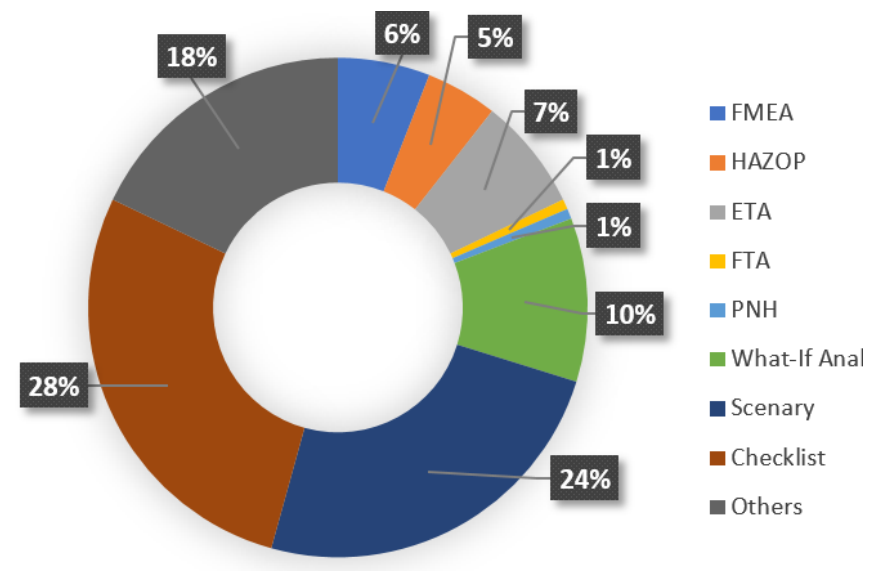

Fig. 2 Methods of the risk management in SME

Fig. 2 shows the use of the methods of risk management in SME. As can be seen, the most used method is the Checklist, scenery, and What-If Analysis. On the other hand, the least used method is
FTA and PNH. Some of these methods use software tools for the results. Like others, the respondents give information, that they not used methods of risk management, internal methods, or EAR (Earings at Risk).

\section{Discussion and Conclusion}

The aim of the paper was risk management and the use of project management software in SMEs in the Czech Republic. As was mentioned, new technologies play an essential role in several areas of human activity today. One of them is the use of software in project risk management.

The first part of the paper has analyzed the risks in SME. The Pareto analysis was used. As can be seen from the results, there are four risks, for which the SME must pay attention. The second part of the results has analyzed the use of methods for risk management in SME. The most used method is the Checklist. This method uses forty percent of the SME. On the other hand, there was not mentioned the use of software project risk management methods.

SMEs have only limited opportunities in terms of knowledge, skills and resources needed to manage project risks. We want to recommend the use of software methods in dealing with risks in SME. This software could be used in the different parts of project risk management.

\section{Acknowledgment}

This research was supported by the GAAA - Project risk management in the conditions of small and 
medium-sized enterprises in the Czech Republic GA/16/2019.

\section{References:}

[1] A. Rostami, J. Sommerville, I. L. Wong, and C. Lee, "Risk management implementation in small and medium enterprises in the UK construction industry," Eng. Constr. Archit. Manag., vol. 22, no. 1, pp. 91-107, 2015.

[2] R. Golej, "Selected Determinants of Mezzanine Financing in Poland," J. Entrep. Manag. Innov., vol. 12, no. 3, pp. 57-84, 2016.

[3] P. Lückmann and C. Feldmann, "Success Factors for Business Process Improvement Projects in Small and Medium Sized Enterprises - Empirical Evidence," Procedia Comput. Sci., vol. 121, pp. 439-445, 2017.

[4] O. for Economic and C. and Development, "OECD." [Online]. Available: https://www.oecd.org/.

[5] H. Forsman, "Business development success in SMEs: A case study approach," J. Small Bus. Enterp. Dev., vol. 15, no. 3, pp. 606622, 2008.

[6] M. Renton, U. Daellenbach, S. Davenport, and J. Richard, "Small but sophisticated: Entrepreneurial marketing and SME approaches to brand management," J. Res. Mark. Entrep., vol. 17, no. 2, pp. 149-164, 2015.

[7] C. B. Chapman and D. F. Cooper, "Risk engineering: Basic controlled interval and memory models," J. Oper. Res. Soc., vol. 34, no. 1, pp. 51-60, 1983.

[8] A. Qazi, J. Quigley, A. Dickson, and K. Kirytopoulos, "Project Complexity and Risk Management (ProCRiM): Towards modelling project complexity driven risk paths in construction projects," Int. J. Proj. Manag., vol. 34, no. 7, pp. 1183-1198, 2016.

[9] V. Urciuoli and G. Crenca, Risk mannagement. 1989.

[10] M. Naaranoja, P. Haapalainen, and H. Lonka, "Strategic management tools in projects case construction project," Int. J. Proj. Manag., vol. 25, no. 7, pp. 659-665, 2007.

[11] Sameh Monir El-Sayegh, "Risk assessment and allocation in the UAE construction industry," Int. J. Proj. Manag., vol. 26, no. 4, pp. 431-438, 2008.

[12] C. Verbano and K. Venturini, "Managing risks in SMEs: A literature review and research agenda," J. Technol. Manag. Innov., vol. 8, no. 3, pp. 186-197, 2013.

[13] P. Taraba, R. Heinzova, K. Pitrova, M. Hart, and J. Trojan, "Project risks in enterprises in the Czech Republic," Proc. 25th Int. Bus. Inf. Manag. Assoc. Int Bus. Informat Manag. Assoc., pp. 814-821, 2015.

[14] Z. Virglerova, K. Dobes, J. Kramolis, and A. Kotaskova, "The influence of SME owners' education on their perception of business environment in Czech Republic," Econ. Sociol., vol. 10, no. 3, pp. 321-332, 2017.

[15] J. Belas, J. Machacek, P. Bartos, R. Hlawiczka, and M. Hudakova, "Business Risks and the Level of Entrepreneurial Optimism among SME in the Czech and Slovak Republic," J. Compet., vol. 6, no. 2, pp. 30-41, 2014.

[16] M. Korecky and V. Trkovsky, Project risk management with a focus on projects in industrial companies. Prague: Grada Publishing, 2011.

[17] J. Doležal, Projektový management. Grada Publishing, 2016.

[18] P. Taraba, M. Hart, and K. Pitrova, "Risk Management Of Projects In The Czech Republic," Polish J. Manag. Stud., vol. 13, no. 1, pp. 181-191, 2016.

[19] H. Kerzner, Project management: a systems approach to planning, scheduling, and controlling, 11. New Jersey: John Wiley \& Sons, 2013.

[20] T. Kendrick, Identifying and Managing Project Risk: Essential Tools for FailureProofing Your Project, 3. New York: American Management Association, 2015.

[21] Hillson David, The Risk Management Handbook: A Practical Guide to Managing the Multiple Dimensions of Risk. Kogan Page, 2016.

[22] PMI, Practice Standard for Project Risk Management. Project Management Institute, 2009.

[23] PMI, A Guide to the Project Management Body of Knowledge (PMBOK® Guide), 6. Project Management Institute, 2017.

[24] IPMA, Individual Competence Baseline. Zurich: International Project Management Association, 2015.

[25] H. Y. Ching and T. M. Colombo, "Enterprise risk management good practices and proposal of conceptual framework," IIE Annu. Conf. Expo 2014, no. January, pp. 139-147, 2014.

[26] P. Rezakhani, "Current state of existing project risk modeling and analysis methods with focus on fuzzy risk assessment - 
Literature review," Frat. ed Integrita Strutt., vol. 20, pp. 17-21, 2012.

[27] M.-Y. Cheng, N.-D. Hoang, A. F. V. Roy, and Y.-W. Wu, "A novel time-depended evolutionary fuzzy SVM inference model for estimating construction project at completion," Eng. Appl. Artif. Intell., vol. 25, no. 4, pp. 744-752, 2012.

[28] F. Tüysüz and C. Kahraman, "Project risk evaluation using a fuzzy analytic hierarchy process: An application to information technology projects," Int. J. Intell. Syst., vol. 21, no. 6, pp. 559-584, 2006.

[29] K. Schwalbe, Project management in IT, Brno: Computers Press, 2011.

[30] A. Svozilova, Project management. Prague: Grada Publishing, 2016.

[31] D. Dvorak, J. Kalia, and J. Sirucek. Championship in Microsoft Project 2010. Computers Press, 2011.

[32] J. Basl and R. Blazicek, Po Business information systems - Enterprise in the information society. Prague: Grada Publishing, 2012.

[33] H. Bartosova, J. Bartos, and P. Ponikelsky, Project management. College of Regional Development, 2012.

[34] J. K. Pinto, Project Management: Achieving Competitive Advantage, 4. Boston, 2016.

[35] M. Grasseova, Effective decision making. 2013.

\section{Creative Commons Attribution License \\ 4.0 (Attribution 4.0 International, CC}

BY 4.0)

This article is published under the terms of the Creative Commons Attribution License 4.0 https://creativecommons.org/licenses/by/4.0/deed.en US 